\title{
Achieving Sustainable Development Goals in the Niger Delta: A Corporate Social Responsibility Pathway
}

\author{
Fidelis Allen ${ }^{1 *}$, Prince Eze ${ }^{1}$
}

${ }^{1}$ University of Port Harcourt, NIGERIA

*Corresponding Author: allfidelis@gmail.com

Citation: Allen, F. and Eze, P. (2019). Achieving Sustainable Development Goals in the Niger Delta: A Corporate Social Responsibility Pathway. European Journal of Sustainable Development Research, 3(4), em0098. https://doi.org/10.29333/ejosdr/5877

Published: August 19, 2019

\begin{abstract}
Is corporate social responsibility (CSR) practice of international oil companies contributing to the achievement of Sustainable Development Goals in the Niger Delta? The international community prescribes a role for business in the good of society. In a similar vein, a significant segment of the literature suggests a positive role for CSR practice. However, adequate analysis of how this is unfolding remains a task yet to be accomplished. This paper examines whether CSR practice in the aforesaid region is contributing to the attainment of SDGs. It focuses on the new CSR model - Global Memorandum of Understanding (GMoU) - initiated in 2005 and 2006 by Chevron and Shell respectively, specifically in relation to goals number one, two and three, which focus on poverty, hunger, better health, and well-being. Relying on data generated from secondary sources, the paper addresses the aforementioned question, and argues that recent oil multinational companies' CSR practice is yet to properly respond to the development needs of local community people.
\end{abstract}

Keywords: CSR, SDGs, GMoU, Shell, Chevron, Host communities, Niger Delta

\section{INTRODUCTION}

The Sustainable Development Goals (SDGs), ratified by the United Nations in September 2015, will not be successfully accomplished by government alone. Non-governmental organizations (NGOs), inter-governmental organizations (IGOs), politicians, chief executive officers (CEOs), managers, including private individuals have roles to play towards actualization of these goals. It appears that both the principles and effective practice of CSR can contribute to the actualization of SDGs (Carroll, 1991; Jones, 1995, 1999; Margolis and Walsh, 2003; McWilliams and Siegel, 2001; Orlitzky, Schmidt and Ryness, 2003). For instance, Nestle and Unilever, Intel, CocaCola and Land O' Lakes International, through CSR, are helping to develop communities in India, Venezuela, Costa Rica and Albania respectively (Amadi and Abdullah, 2011).

Corporations in the Delta apply the CSR model on individual basis. Going by Friedman's (1970) argument about profit as the main justification why companies are in business, corporations tend to see no good reason for CSR. For Friedman, engaging in any act apart from business is totally unnecessary. Explanations for this kind of position exist, including the unavoidable truth that corporations are in business to make profit, while paying necessary tax to authorities. Government has a providing responsibility of citizens with essential amenities and other social services. Those who share this view include Reich $(2007,2008,2010)$, who provided economic and moral reasons why corporations should not practice CSR in modern times.

Corporations that, however, consider the value of being socially responsible take side with Freeman (1984), who argued that these business organizations must satisfy the yearning of other stakeholders and not just 
shareholders. Communities, personnel, and the citizenry are the other critical stakeholders that also require the attention of corporations, since their activities also impact on them. Those who refused to consider the good reasons for CSR do not clarify what is wrong with complementing government efforts at providing social services especially in less developed economies. Regarding the Niger Delta, decades of oil drilling have led to massive pollution of the environment, denying many access to fresh water and other resources that previously added value to life. In addition, livelihood opportunities have shrunk, leaving many without adequate sources of income and food for households (Bayode, Adewunmi and Odunwole, 2011). Giving a little back to communities faced with these dilemmas by oil companies has therefore been noted as worthwhile. Oil companies have faced resistance and grievances from their host communities, warranting some form of corporate social responsibility initiatives. Since business is an arm of social formation, and the social license for them to carry on with operation is crucial in the short and longer term, many believe CSR should not be a bad idea after all.

Based on the foregoing, this study deploys qualitative content analysis to examine whether the GMoU model of CSR practiced by two international oil companies (Chevron and Shell) is contributing to the realization of SDGs 1, 2 and 3, which among others relate to hunger, poverty and health in the Delta region.

\section{CONCEPTUAL ISSUES: CSR AND GMoU}

CSR is used interchangeably with corporate sustainability (CS), corporate citizenship (CC), corporate governance (CG), corporate accountability (CA), ethical corporation (EC), among others (Ismail, 2009: 50; Rahim, 2013: 29; Swapna, 2011: 24). Undoubtedly, the concept lacks a universally accepted definition (Uddin, Hassan and Tarique 2008: 33; WBCSD, 2000: 45). One reason cited for this is the over-dynamic nature of CSR and continual demand for it by the society. Importantly, definitions given to the concept vary from institution to institution, depending on environmental factors (Idemudia, 2009).

The most controversial view of CSR was given by Friedman (1970: 126). He maintained that: "There is one and only one social responsibility of business- to use its resources and engage in activities designed to increase its profit so long as it stays within the rules of the game, which is to say, engages in open and free competition without deception or fraud". This interpretation elicited several responses from scholars from the different divides. Its reactions also helped in widening the gap on CSR literature. The view is ingrained in the shareholder approach which fails to consider other stakeholders other than shareholders who invest resources (capital).

The desire to locate a definition of CSR with wide recognition and acceptance perhaps informed Dahlsrud's (2006) decision to review 37 definitions. The research cut across the years 1980-2003 and had five dimensions, namely: voluntariness, social, economic, stakeholder, and environment. His Google search and counts produced results, one of which was that definition submitted by the European Commission (EC) has the topmost frequency count (286). Operationally, this paper has been influenced by this definition. CSR is therefore a concept that conveys the idea of companies integrating "...social and environmental concerns in their business operations and in their interactions with their stakeholders on a voluntary basis" (EC, 2001: 8).

\section{GMoU INITIATIVE}

The GMoU is a new CSR model deployed by international oil companies (IOCs) in Nigeria. It was pioneered by Chevron Nigeria Ltd in 2005 and adopted by SPDC Ltd in 2006. It is an agreement between these companies and their host communities, with defined structures of governance and implementation. The agreement usually states the method of operation of the company, and intended benefits to communities when it comes to development. According to Draper (2010: 87).

Each of Chevron and Shell's GMOUs is signed between the company and representatives of the several dozen communities which will benefit under it. The agreement calls for and creates a single central leadership board for each GMOU, called Regional Development Councils (RDCs) in Chevron's program and Cluster Development Boards (CDBs) under the Shell system. Leadership is drawn from the local elite and community representatives, the companies, state and local governments, the NDDC and civil society. Member communities may also be represented by local governance bodies like community trusts (CTs).

Shell GMoU community board consists of chairpersons of the CT, their secretaries, a member (a woman, if the chairperson or the secretary is not a woman), an SPDC representative, representatives from the different levels of government, Niger Delta Development Commission (NDDC) representative and a representative from NAPIMS. The Community Trust (CT) and Cluster Development Board (CDB) have the overriding duty of enforcing $\mathrm{GMoU}$ policies and projects. The $\mathrm{CT}$ and $\mathrm{CDB}$ while having separate duties, also have areas of overlap. 


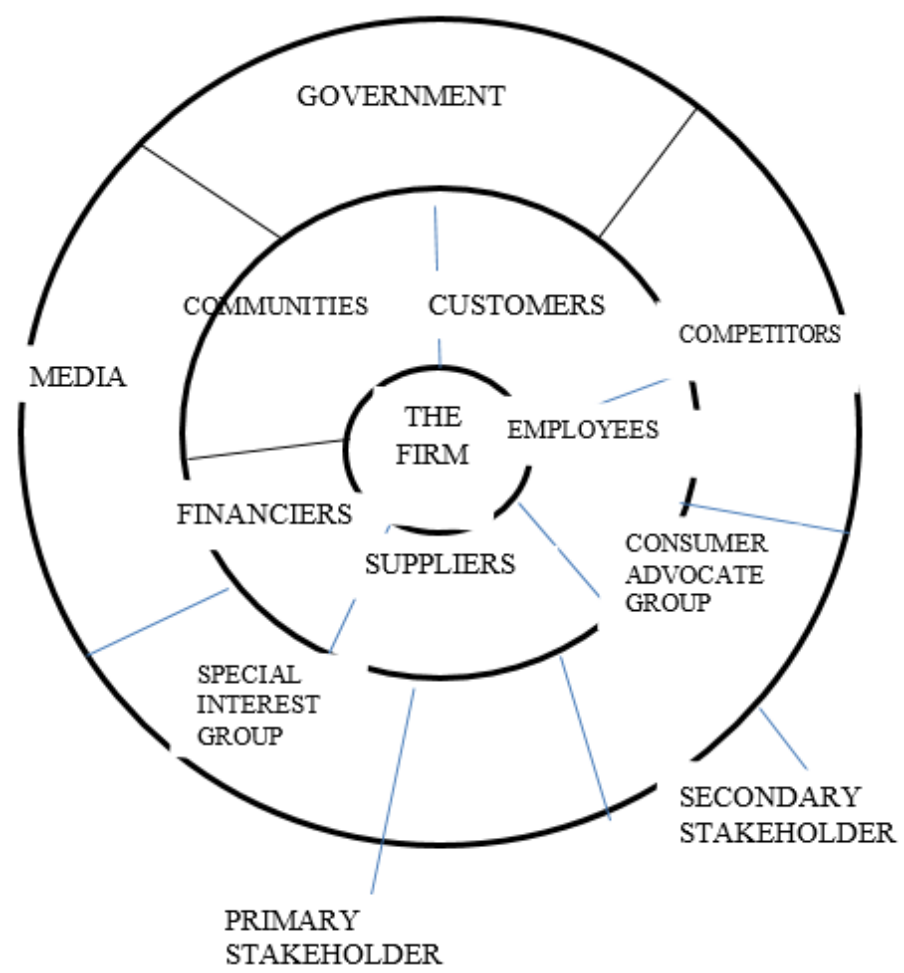

Figure 1. Stakeholders Approach

Source: Freeman, Harrison and Wicks (2007: 24)

\section{THEORETICAL FRAMEWORK}

Freeman (1984) opposed the predominant and most critical views of CSR, and advanced a Stakeholder Theory. This, he did achieve by providing new insights into the purpose of corporations in society. In his influential book "Strategic Management: A Stakeholder Approach" Freeman (1984) defined a stakeholder as "any group or individual who can affect or is affected by the achievement of the organizational objectives". It is debated that "the goal of any company is or should be the flourishing of the company and all its principal stakeholders" (Wehane and Freeman, 1999). The idea backing this thinking has as well been summarized thus: "that to perform well, managers need to pay attention to a wide array of stakeholders, and that managers have obligations to stakeholders which include, but extend beyond, shareholders". (Jones, 2002: 20). Freeman, Harrison and Wicks (2007) went further to state the different categorizes of people equally affected by activities of a business organization (See Figure 1).

What this suggests is that corporations engage in CSR with the motive of giving back to people impacted by their operations. The essence is to contribute to solving societies' many social problems. As earlier noted, Development Goals, number 1, 2 and 3 relate to poverty, hunger, better health, and well-being. There are firm impressions and expectations that CSR projects should help reduce these problems and by so doing move society towards achieving these goals. This is however, not the experience in the region under consideration. Corporations seem clearly to have politicized CSR. Assessment of the GMoU model, introduced in 2005 and 2006 by Chevron and Shell respectively in this province, suggests reasons for engaging in CSR by the IOCs in the Delta. As stated by Frynas (2005:583), the reasons are "obtaining competitive advantage, maintaining a stable environment, managing external perception and keeping employees happy".

\section{THE SDGs AND CSR IN THE DELTA}

The Delta region is vexed with enormous development challenges. Nigeria's oil industry, driven by international oil companies, has affected the environment in the region, and created conditions for economic hardship for host community people, who keep arguing that more work is needed to cushion the negative outcomes of oil company operations (Emmanuel, 2009). 
Table 1. GMoU initiative in the Delta region

\begin{tabular}{|c|c|c|}
\hline Item & Commitments & Project status \\
\hline \multicolumn{3}{|l|}{ Infrastructure } \\
\hline Water supply & $\begin{array}{l}\text { Provide Gbarain and Ekpetiama kingdoms with reliable source } \\
\text { of potable water and installation of appropriate water supply } \\
\text { facilities/equipment } \\
\text { Build local capacity to efficiently operate and manage the water } \\
\text { facilities }\end{array}$ & $\begin{array}{l}\text { No functional or successful water supply } \\
\text { Saipem is trucking water } \\
\text { A few youths trained but not gainfully } \\
\text { employed }\end{array}$ \\
\hline Electricity supply & $\begin{array}{l}\text { Connect communities power supply system } \\
\text { To align with the BSEB on power supply system } \\
\text { Provide electricity back-up for Gbarantoru and Obunagha from } \\
\text { the central processing facility when built and after energy } \\
\text { demand analysis }\end{array}$ & $\begin{array}{l}\text { No positive action } \\
\text { No action } \\
\text { No electricity yet }\end{array}$ \\
\hline Community roads & $\begin{array}{l}\text { Rehabilitate/construct of roads (of internal road networks), } 7 \\
\mathrm{~km} \text { in Gbarain and Ekpetiama kingdoms }\end{array}$ & $\begin{array}{l}\text { No internal road construction begun in } \\
\text { place }\end{array}$ \\
\hline $\begin{array}{l}\text { Gbarain kingdom civic } \\
\text { centre hall }\end{array}$ & $\begin{array}{l}\text { Construct a civic centre hall including basic sporting equipment } \\
\text { for Gbarain kingdom; jointly determined by Gbarain kingdom } \\
\text { and SPDC }\end{array}$ & $\begin{array}{l}\text { Civic centre hall completed but no } \\
\text { equipment or agreed facilities }\end{array}$ \\
\hline $\begin{array}{l}\text { Upgrade of town halls for } \\
\text { Ekpetiama }\end{array}$ & $\begin{array}{l}\text { Upgrade existing town halls for Ekpetiama kingdom; design and } \\
\text { scope to be jointly determined by Ekpetiama kingdom and } \\
\text { SPDC }\end{array}$ & Not yet upgraded \\
\hline $\begin{array}{l}\text { Construction of school } \\
\text { blocks }\end{array}$ & $\begin{array}{l}\text { Construct a block of six classrooms in Obunagha and in } \\
\text { Gbarantoru }\end{array}$ & Not yet implemented \\
\hline \multicolumn{3}{|l|}{ Health projects } \\
\hline Health centres & $\begin{array}{l}\text { Construct and equip two health centres at Gbaraintoru and } \\
\text { Ogboloma }\end{array}$ & $\begin{array}{l}\text { Health centres constructed but not } \\
\text { equipped or commissioned }\end{array}$ \\
\hline $\begin{array}{l}\text { Construction of health } \\
\text { posts }\end{array}$ & $\begin{array}{l}\text { Construct and equip two health posts at Obunagha and } \\
\text { Bumoundi-Gbene }\end{array}$ & $\begin{array}{l}\text { Health posts constructed but not equipped } \\
\text { or commissioned }\end{array}$ \\
\hline $\begin{array}{l}\text { Provision of hospital } \\
\text { equipment }\end{array}$ & $\begin{array}{l}\text { Complement Bayelsa State to furnish the two hospitals at } \\
\text { Okoloibiri and Agudama }\end{array}$ & No action taken \\
\hline \multicolumn{3}{|c|}{ Human capital development } \\
\hline $\begin{array}{l}\text { Support for the kingdoms' } \\
\text { local employment bureau }\end{array}$ & Formation of a dedicated oil and gas employment bureau & $\begin{array}{l}\text { Employment bureau established but } \\
\text { provides only minimal employment } \\
\text { opportunities }\end{array}$ \\
\hline Youth training & $\begin{array}{l}\text { Continue with the planned youth training schemes agreed with } \\
\text { Bayelsa and Saipem at Port Harcourt, Petroleum Training } \\
\text { Institute at Warri and Technical College at Ekowe }\end{array}$ & No evidence of progress \\
\hline Scholarship awards & $\begin{array}{l}80 \text { post-secondary scholarships to indigenes of Gbarain and } \\
\text { Ekpetiama kingdoms who pass qualifying test }\end{array}$ & No evidence of progress \\
\hline $\begin{array}{l}\text { Provision of craft, technical } \\
\text { and laboratory equipment }\end{array}$ & $\begin{array}{l}\text { Equip craft centres at Polaku and Agudama to provide basic } \\
\text { craft training; } \\
\text { Provide science laboratory equipment in three schools } \\
\text { Provide laboratory equipment in five schools }\end{array}$ & $\begin{array}{l}\text { Implemented } \\
\text { Laboratory equipment supplied instead of } \\
\text { intro-tech } \\
\text { Implemented }\end{array}$ \\
\hline \multicolumn{3}{|c|}{ Economic empowerment } \\
\hline $\begin{array}{l}\text { Economic empowerment } \\
\text { projects }\end{array}$ & $\begin{array}{l}\text { Provide N200 million for economic empowerment } \\
\text { Provide four 14-seater buses for Gbarain and Ekpetiama } \\
\text { kingdoms including driver training }\end{array}$ & $\begin{array}{l}\text { Not fulfilled } \\
\text { Implemented }\end{array}$ \\
\hline \multicolumn{3}{|l|}{ Public relations } \\
\hline Sand stockpile & $\begin{array}{l}\text { provide two 5,000 cum stockpiles of sand for the Gbarain and } \\
\text { Ekpetiama kingdoms }\end{array}$ & $\begin{array}{l}\text { Stockpiles provided but wasting away; } \\
\text { because no sharing formula was agreed, } \\
\text { landowners where the piles were deposited } \\
\text { seized the piles, resulting in social conflict }\end{array}$ \\
\hline
\end{tabular}

Source: Emmanuel (2010)

Projects initiated by the international companies in focus, under the GMoU, clearly put forward that if fully implemented, should assist in the wellbeing of local community people. Visit to these oil bearing communities revealed uncertainty about the value of these projects in the direction that they were intended to go. SDG goals number one, two and three can be pursued with these projects. As seen in Table 1, there are numerous problems that make it complex for these projects to make vital input to the actualization of the SGD goals. For example, insincerity of corporations, lack of adequate execution and abandonment of project. 


\section{ACHIEVING SDGs IN THE DELTA REGION}

Prospect of realizing SDGs via effective CSR initiatives in the Delta is doubtful. Political elites in public decision-making positions hardly retrace their steps to realizing the damage which the lack of effective implementation of economic policies cause the wellbeing of people in their countries. Poor governance of natural resources is a feature in many resource endowed countries in Africa. The realization of the SDGs in these countries depends on how strong social, economic and political institutions are with implementation of development policies or projects.

Challenges confronting these goals are numerous. Principal among them is the weak economic, political and social institutions in Africa. As already suggested, the fight against poor implementation is serious. Blindness of political elites to troubling failed implementation of CSR projects through effective monitoring and establishment of a relevant policy framework, remains equally crucial.

Pursuit of SDGs, via CSR lacks legal backing. The seeming voluntary nature of the GMoU model, creates an atmosphere of evasiveness for the companies, who seem to have found a way through the ineffectiveness of the model to retreat from ethical demands of ensuring adequate compensation to communities who suffer severely from their activities. Importantly, a local economic elite or class is evolving from the practice. The danger is in the interest and motivation which the class now has in relation to overall community interests. Oil companies, easily have developed an alliance with this class, as reflected in the leadership structures of the model. The pursuit of private interest by those who occupy these structures, run contrary to both short and longer term interests of communities.

Notwithstanding, CSR projects may offer opportunities for short term palliative improvements in the living conditions of communities through provision of some social amenities, in context of peace and conflict management.

\section{CONCLUSION}

This paper has discussed how CSR models of Chevron and Shell assist in the achievement of SDGs number one, two and three in the Delta region. Clearly, this is not happening as expected for a variety of reasons, including lack of sincerity on the part of the MNCs. In addition, lack of full implementation of projects and related complexities of the inability of capital to deal with the questions of hunger, poverty and poor access to healthcare at the grassroots. CSR projects undertaken by these MNCs are rather palliative steps taken to maintain social licenses to remain in business. However, the paper acknowledges the positive role that CSR can play in the distribution of services. The SDGs cannot be realized by government alone. It means society can improve the wellbeing of its people when business, government and other establishments play individual contributory roles in the provision of infrastructure. What is now crucial is for every group to understand this role in the case of the Niger Delta, and take the required steps towards making the SDGs realizable, through more funding of projects.

\section{REFERENCES}

Amadi, B. and Abdullah, H. (2011). Evaluating Multi-Sector Partnership for Sustainable Development. Canadian Social Science Journal, 7(16).

Bayode, A. J., Adewunmi, E. A. and Odunwole, S. (2011). Environmental implications of oil exploration and exploitation in the coastal region of Ondo State, Nigeria: A regional planning appraisal. Journal of Geography and Regional Planning, 4(3), 110-121.

Carroll, A. B. (1999). Corporate Social Responsibility- Evolution of Definitional Construct. Business and Society, 38(3), 268-295. https:// doi.org/10.1177/000765039903800303

Dahlsrud, A. (2006). How Corporate Social Responsibility is Defined: An Analysis of 37 Definitions. Corporate Social Responsibility and Environmental Management, 15,1-13. https://doi.org/10.1002/csr.132

Draper, T. (2010). Shell in Nigeria: A Conflict Perspective. In Ecumenical Council for Corporate Responsibility (Eds) pp.51-64, Shell in Niger Delta: A framework for Change five case studies from Civil Society. Oxford, United Kingdom.

Emmanuel, E. O. (2010). Shell in Nigeria: A Conflict Perspective. In Ecumenical Council for Corporate Responsibility (Eds) pp. 51-64, Shell in Niger Delta: A framework. for Change five case studies from Civil Society. Oxford, United Kingdom.

European Commission (EC). (2001). Green Paper. Promoting a European Framework for Corporate Social Responsibility. Available at: http:/ / europa.eu/rapid/press-release_DOC-01-9_en.pdf

Freeman, O. (1981). The Multinational Company: Instrument for World Growth. New York: Praeger. 
Freeman, R. E., Haarrison, J. S. and Wicks, A. C. (2007). Managing for Stakeholders: Business in the 21 st Century. Managing for Stakeholders: Survival, Reputation, and Success. New Haven: Yale University Press.

Freeman, R. E., Wicks, A. C. and Parmar, B. (2004) Stakeholder Theory and The Corporate Objective Revisited, Organization Science, 15(3), 364-369. https:// doi.org/10.1287/orsc.1040.0066

Friedman, M. (1970). The Social Responsibility of Business is to Increase its Profits. New York Times Magazine, 13 September 1970: 33.

Frynas, J. G. (2005). The False Development Promise of Corporate Social Responsibility: Evidence from Multinational Oil Companies. International Affairs, 8193, 581-598. https://doi.org/10.1111/j.14682346.2005.00470.x

Idemudia, U. (2009). Oil Extraction and Poverty Reduction in the Niger Delta: A Critical Examination of Partnership Initiatives. Journal of Business Ethics, 90, 91-116. Retrieved from http:/ /www.jstor.org/stable/40295087

Ismail, M. (2009). Corporate Social Responsibility and Its Role in Community Development: An International Perspective. The journal of International Social Research, 2(9), 199-209.

Jones, T. M. (1999). The institutional determinants of social responsibility. Journal of Business Management Review, 20(2).

Margolis, D. and Walsh, P. (2003). Misery loves companies: Rethinking social initiatives by business. Administrative Science Quarterly, 48(2), 268-305. https:// doi.org/10.2307/3556659

McWilliams, A. and Siegel, D. (2001). Corporate social responsi bility: A theory of the firm perspective. Academy of Manage ment Review, 26(1), 11 7-1. https://doi.org/10.2307/259398

Orlitzky, M., Schmidt, F. L. and Rynes, S. L. (2003). Corporate social and financial performance: A meta-analysis. Organization Studies, 24(3), 403-420. https://doi.org/10.1177/0170840603024003910

Rahim, M. M. (2013). Legal Regulation of Corporate Social Responsibility: A Meta-Regulation Approach of Law for Raising CSR in a Weak Economy, Berlin: Springer-Verlag. https://doi.org/10.1007/978-3-642-28036-8_710

Reich, R. B. (2007). Supercapitalism: The Transformation of Business, Democracy; and Everyday Life. New York: Random House.

Swapna, P. (2011). Role of Coporate Social Responsibility in Community Development. VSRD International Joumal of Business and Management Resarch, 1(9), 594-601.

Uddin, M. B., Hassan, M. R., and Tarique, K. M. (2008). Three Dimensional Aspects of Corporate Social Responsibility. Daffodil International University Journal of Business and Economics, 3(1), $199-212$.

Werhane, P. H. and Freeman, R. E. (1999) Business ethics: the state of the art. International Journal of Management Reviews, 1(1), 1-16. https://doi.org/10.1111/1468-2370.00002

World Business Council on Sustainable Development (2000). Corporate Social Responsibility: Making Good Business Sense. Geneva. 